\title{
Comparison of Ethanol Degradation Pathways in Anoxic Freshwater Environments
}

\author{
By BERNHARD SCHINK, ${ }^{1}$ * TOM J. PHELPS, ${ }^{2}$ BARBARA EICHLER \\ AND J. G. ZEIKUS ${ }^{2}$ \\ ${ }^{1}$ Fakultät für Biologie, Universität Konstanz, Postfach 55 60, D-7750 Konstanz, FRG \\ 'Department of Bacteriology, University of Wisconsin, Madison, W 53706, USA
}

(Received 12 June 1984; revised 9 October 1984)

\begin{abstract}
Pool sizes, turnover times and turnover rates of ethanol and acetate in anoxic sediments of Lake Mendota and Knaack Lake and in anoxic sewage digestor sludge were determined by gas chromatography-gas proportional counting techniques. Ethanol accounted for 6,14 and $2.5 \%$ of the total carbon flux to methane in these environments, respectively. The distribution of labelled carbon in the methane and carbon dioxide fractions obtained during incubation of the anoxic materials with $\mathrm{C}-1$ and $\mathrm{C}-2$ labelled acetate and ethanol revealed a significantly higher degree of randomization with ethanol than with acetate tracers. HPLC analysis of sediment pore water preparations revealed that labelled acetate and propionate were formed as intermediates of labelled ethanol degradation, whereas no labelled butyrate was detected. Addition of hydrogen to Knaack Lake sediment samples inhibited ethanol degradation drastically and led to a significant accumulation of labelled butyrate. The above findings together with the results of most probable number enumerations of anaerobic ethanol-degrading bacteria indicate that propionate-forming bacteria contributed significantly to ethanol degradation in Knaack Lake sediment and in sewage sludge.
\end{abstract}

\section{INTRODUCTION}

Ethanol is an important product of anaerobic fermentations. Yeasts as well as facultatively and strictly anaerobic bacteria produce considerable amounts of ethanol in pure culture; however, the importance of ethanol metabolism in microbial communities in natural anoxic habitats such as lake sediments is largely unknown. Since the formation of reduced fermentation products like ethanol is energetically less favourable than the formation of acetate with concomitant transfer of hydrogen to hydrogen-scavenging bacteria (Tewes \& Thauer, 1980), the latter process is presumed to be preferred under substrate-limiting conditions in natural habitats. Mixed-culture experiments with ethanol-producing and hydrogen-oxidizing anaerobes demonstrated that interspecies hydrogen transfer shifts the fermentation pattern of the former bacteria from ethanol to nearly exclusively acetate, hydrogen and carbon dioxide (Iannotti et al., 1973; Weimer \& Zeikus, 1977; Schink \& Zeikus, 1982). Nevertheless, small amounts of ethanol are formed in anoxic environments and give rise to a small ethanol pool in the micromolar range in sewage sludge (Kaspar \& Wuhrmann, 1978) and in lake sediments (Lovley \& Klug, 1982; Phelps \& Zeikus, 1984; T. J. Phelps \& J. G. Zeikus, unpublished data). Since ethanol does not accumulate to higher concentrations, anaerobic ethanol degradation must counteract ethanol formation in situ.

In the presence of sulphate, ethanol is oxidized to acetate by classical sulphate-reducing bacteria with concomitant reduction of sulphate to sulphide (Postgate, 1979). In the absence of sulphate, these bacteria can couple ethanol oxidation with interspecies hydrogen transfer to 
methanogens (Bryant et al., 1977). A similar syntrophic association, converting ethanol and carbon dioxide to acetate and methane, was described as 'Methanobacillus omelianskii' (Barker, 1936) in which the 'S-organism' fulfils the function of Desulfovibrio sp. (Bryant et al., 1967). Some homoacetogenic bacteria, e.g. Clostridium aceticum (Braun et al., 1981) or Acetobacterium carbinolicum (Eichler \& Schink, 1984), combine ethanol oxidation to acetate with reductive acetate formation from carbon dioxide. Clostridium kluyveri ferments acetate and ethanol to butyrate (Barker, 1937; Bornstein \& Barker, 1948). Recently, a further method of ethanol fermentation has been discovered in Desulfobulbus propionicus and Pelobacter propionicus, which both form propionate as the reduced end product (Samain et al., 1982; Laanbroek et al., 1982; Schink, 1984).

The present study was undertaken in order to compare the specific pathways and organisms involved in ethanol degradation in the neutral sediment of eutrophic Lake Mendota, the mildly acidic sediment of dystrophic Knaack Lake, and in the sludge from an anaerobic sewage digestor.

\section{METHODS}

Entironments and sampling procedures. These were as described in the preceding paper (Schink, 1985).

Pool size determinations. Pool sizes of acetate and ethanol were assayed by direct gas chromatographical analysis of acidified pore water samples. Acetate was also assayed in pore water concentrates obtained by evaporation after alkalinization [see the preceding paper (Schink, 1985)]. Samples $(5 \mu 1)$ were injected into a Sigma 3B gas chromatograph (Bodenseewerke Perkin-Elmer, Überlingen, FRG) equipped with a flame ionization detector and an integrator for peak area analysis. The separation column $(2.0 \mathrm{~m} \times 6 \mathrm{~mm})$ contained Chromosorb WAW, $8 \%$ SP $1000+1 \% \mathrm{H}_{3} \mathrm{PO}_{4}, 100-120$ mesh (Bodenseewerke Perkin-Elmer), and was operated at $90{ }^{\circ} \mathrm{C}$.

Determination of turnoter times and rates. The experimental procedures were as described in the preceding paper (Schink, 1985). Turnover times were calculated from plots of produced ${ }^{1+} \mathrm{CH}_{\downarrow}$ and ${ }^{1+} \mathrm{CO}_{2}$ versus time by extrapolating the linear part of the curves to the amount of total label turned over at the end of the experiment. It has to be emphasized that the turnover times thus calculated only represent apparent turnover times which, in the case of ethanol, refer to a series of two or more reactions. The pool sizes were divided by the respective turnover times in order to obtain the turnover rates.

Analysis of lahelled intermediates of ethanol degradation. Fresh sediment and sewage sludge samples ( $10 \mathrm{ml}$ each) were transferred into anaerobic pressure tubes in the same way as for the turnover determinations. Carrier-free radioactive ethanol (about $2.0 \mu \mathrm{Ci}$ per tube; $1 \mu \mathrm{Ci}=37 \mathrm{kBq}$ ) was added by a microlitre syringe, and the tubes were incubated at the in situ temperatures. Samples $(2 \mathrm{ml})$ were removed by plastic syringes with 18 gauge needles, transferred into Eppendorf plastic vials, and centrifuged at $10000 \mathrm{~g}$ for $5 \mathrm{~min}$. The supernatants were removed with Pasteur pipettes, acidified with $3 \cdot 3 \mathrm{M}-\mathrm{H}_{3} \mathrm{PO}_{4}$, and stored at $-20{ }^{\circ} \mathrm{C}$ for further analysis.

A Perkin Elmer series 3 liquid chromatograph was used for the separation of labelled liquid intermediates of ethanol degradation. An LC-15 UV detector was combined with a Sigma 10 chromatography data station. The separation column (Aminex HPX-87, $300 \times 7.8 \mathrm{~mm}, 125-0140$; Bio-Rad, Richmond, Calif., USA) was equilibrated with sulphuric acid solution $\left(7.5 \mathrm{mmol}^{-1}\right)$ which was prepared with Millipore Ultrapure water filtered through Millipore filters $\left(0.2 \mu \mathrm{m}\right.$ pore diameter). The flow rate was $0.7 \mathrm{ml} \mathrm{min}^{-1}$ at a column pressure of 10 12 bar. ${ }^{1+} \mathrm{C}$-labelled acetate, propionate, ethanol and butyrate were injected separately and in combinations and were found to be separated completely under these conditions. Fractions of five drops each $(0 \cdot 3 \mathrm{ml})$ were collected with a fraction collector in small counting vials. For radioactivity measurement, 5 ml Aquasol scintillation fluid was added to each fraction, and the vials were analysed in a Packard Tri-Carb liquid scintillation counter. Samples $(200 \mu \mathrm{l})$ of each acidified pore water preparation were injected, and 40 fractions (in the range from acetate to butyrate) were collected and counted in each experiment. Peaks were identified by retention times which were checked by coinjection experiments.

Enumeration procedures. Ethanol-degrading anaerobic bacteria were enumerated by the three-tube most probable number (MPN) technique. Samples were diluted in carbonate-buffered mineral medium (Widdel $\&$ Pfennig, 1981) containing $10 \mathrm{mmol}$ ethanol $\mathrm{1}^{-1}$ as the sole organic carbon source. Tubes were incubated for 4 weeks at $28^{\circ} \mathrm{C}$ and then assayed for turbidity and fermentation products formed. Most probable numbers were calculated from standard tables (American Public Health Association, 1969).

Pure culture experiments. Growth experiments were done with Clostridium aceticum DSM 1496 (Braun et al., 1981), Acetohacterium carbinolicum (Eichler \& Schink, 1984) and Pelobacter propionicus DSM 2379 (Schink, 1984). The cultures were grown in mineral medium (Widdel \& Pfennig, 1981), with or without $0.05 \%$ yeast extract, in $17 \mathrm{ml}$ Bellco tubes sealed with butyl rubber septa. Growth was measured at $650 \mathrm{~nm}$ by direct insertion of tubes into a Bausch and Lomb Spectronic 70 spectrophotometer.

Chemicals and radioactive tracers. All chemicals were of reagent or analytical grade quality and were obtained from Sigma, Mallinckrodt (Paris, Ky., USA), or Merck. Gases were purchased from Matheson (Joliet, Ill., USA) 
or Messser Griesheim (Frankfurt, FRG). [1-14 C]Acetate $\left(54.9 \mathrm{mCi} \mathrm{mmol}^{-1} ; 2.03 \mathrm{GBq} \mathrm{mmol}^{-1}\right.$ ) and $\left[2-^{-14} \mathrm{C}\right]$ acetate $\left(51.0 \mathrm{mCi} \mathrm{mmol}^{-1} ; 1.89 \mathrm{GBq} \mathrm{mmol}^{-1}\right)$ were obtained from New England Nuclear. Ethanol present in the tracer preparations was removed by vacuum drying after alkalinization. $\left[1-1^{+4} \mathrm{C}\right]$ Ethanol $\left(59 \cdot 2 \mathrm{mCi} \mathrm{mmol}^{-1}\right.$; $\left.2 \cdot 19 \mathrm{GBq} \mathrm{mmol}^{-1}\right)$ and $[2-1+\mathrm{C}]$ ethanol $\left(20 \mathrm{mCi} \mathrm{mmol}^{-1} ; 0.74 \mathrm{GBq} \mathrm{mmol}^{-1}\right)$ were obtained from Amersham.

\section{RESULTS}

\section{Determination of ethanol and acetate turnover}

Pool sizes, turnover times and turnover rates of ethanol were determined in two different lake sediments and in anoxic sewage sludge of a municipal sewage treatment plant. Table 1 compares the results for ethanol representatives of at least four independent determinations with the respective data obtained for acetate. These results show that ethanol degradation contributed only to a small extent (about 6 and $3 \%$ ) to the total methane formation in Lake Mendota and sewage sludge, but accounted for about $14 \%$ of total methane formation in Knaack Lake sediment.

Comparison of the final distribution of labelled carbon in the methane and carbon dioxide fractions derived from C-1 and C-2 labelled acetate and ethanol indicated that acetate was not the only intermediate of ethanol degradation (Table 2). The $\mathrm{C}-1$ atom of labelled acetate appeared to about $95 \%$ as carbon dioxide, whereas the C-1 atom of ethanol only appeared to 80 $84 \%$ as carbon dioxide, the remaining label being converted to methane. Control experiments with C-2 labelled tracers demonstrated that this result was not simply due to the use of a more reduced tracer; the $\mathrm{C}-2$ atom of labelled ethanol was converted to carbon dioxide to a much higher extent $(12-40 \%)$ than the $\mathrm{C}-2$ atom of acetate $(2 \cdot 5-19 \cdot 5 \%)$. Therefore, experiments were initiated to check for intermediates of ethanol degradation other than acetate.

Table 1. Pool sizes, turnover times and turnover rates of acetate and ethanol in sediments of Lake Mendota and Knaack Lake and in sewage digestor sludge

The results are shown \pm the range.

\begin{tabular}{|c|c|c|c|c|}
\hline & & Mendota & Knaack & Sewage \\
\hline Pool size $\left(\mu \mathrm{mol} \mathrm{1^{-1 }}\right)$ & $\left\{\begin{array}{l}\text { Acetate } \\
\text { Ethanol }\end{array}\right.$ & $\begin{aligned} 17 \cdot 5 & \pm 2 \cdot 5 \\
28 & \pm 5\end{aligned}$ & $\begin{aligned} 240 & \pm 120 \\
78 & \pm 17\end{aligned}$ & $\begin{array}{l}360 \pm 100 \\
113 \pm 60\end{array}$ \\
\hline Turnover time* (h) & $\left\{\begin{array}{l}\text { Acetate } \\
\text { Ethanol }\end{array}\right.$ & $\begin{array}{c}0.31 \pm 0.06 \\
5.5 \pm 0.4\end{array}$ & $\begin{array}{l}40 \cdot 0 \pm 8 \cdot 0 \\
85 \cdot 0 \pm 5 \cdot 0\end{array}$ & $\begin{array}{l}1.2 \pm 0.1 \\
9.0 \pm 0.1\end{array}$ \\
\hline Turnover rate $\left(\mu \mathrm{mol} 1^{-1} h^{-1}\right)$ & $\left\{\begin{array}{l}\text { Acetate } \\
\text { Ethanol }\end{array}\right.$ & $\begin{array}{r}56 \cdot 5 \\
5 \cdot 1\end{array}$ & $\begin{array}{l}6.0 \\
0.92\end{array}$ & $\begin{array}{r}300 \cdot 0 \\
12 \cdot 6\end{array}$ \\
\hline Total methane formation $\dagger(\mu$ & $\left.1^{-1} h^{-1}\right)$ & $83.9 \pm 24$ & $6 \cdot 4 \pm 2 \cdot 2$ & $468 \pm 48$ \\
\hline
\end{tabular}

* Turnover times were determined as described in Methods with $\left[2-{ }^{1+} \mathrm{C}\right]$ acetate and $[2-1+\mathrm{C}] \mathrm{ethanol}$ as tracers.

+ Means of total methane formation rates in all the experimental tubes used.

Table 2. Formation of labelled $\mathrm{CH}_{4}$ and $\mathrm{CO}_{2}$ during incubation of tracers with sediment and sludge samples

Values are percentages of the total label recovered as ${ }^{14} \mathrm{CO}_{2}$ and ${ }^{1+} \mathrm{CH}_{4}$, and are the means of between four and six independent assays.

\begin{tabular}{|c|c|c|c|c|c|c|}
\hline & \multicolumn{2}{|c|}{ Mendota } & \multicolumn{2}{|c|}{ Knaack } & \multicolumn{2}{|c|}{ Sewage } \\
\hline & ${ }^{1+\mathrm{CH}_{4}}$ & ${ }^{1+} \mathrm{CO}_{2}$ & ${ }^{1+} \mathrm{CH}_{4}$ & ${ }^{1+} \mathrm{CO}_{2}$ & ${ }^{1+} \mathrm{CH}_{4}$ & ${ }^{14} \mathrm{CO}_{2}$ \\
\hline$[1-1+C]$ Acetate & $3 \cdot 3$ & $96 \cdot 7$ & $4 \cdot 8$ & $95 \cdot 2$ & $5 \cdot 8$ & $94 \cdot 2$ \\
\hline$[2-1+C]$ Acetate & $87 \cdot 4$ & $12 \cdot 6$ & $80 \cdot 5$ & $19 \cdot 5$ & $97 \cdot 5$ & $2 \cdot 5$ \\
\hline$[1-1+C]$ Ethanol & 15.9 & $84 \cdot 1$ & $15 \cdot 5$ & $84 \cdot 5$ & $19 \cdot 4$ & $80 \cdot 6$ \\
\hline$\left[2-^{1+} \mathrm{C}\right]$ Ethanol & $79 \cdot 9$ & $20 \cdot 1$ & $60 \cdot 2$ & $39 \cdot 8$ & $87 \cdot 6$ & $12 \cdot 4$ \\
\hline
\end{tabular}




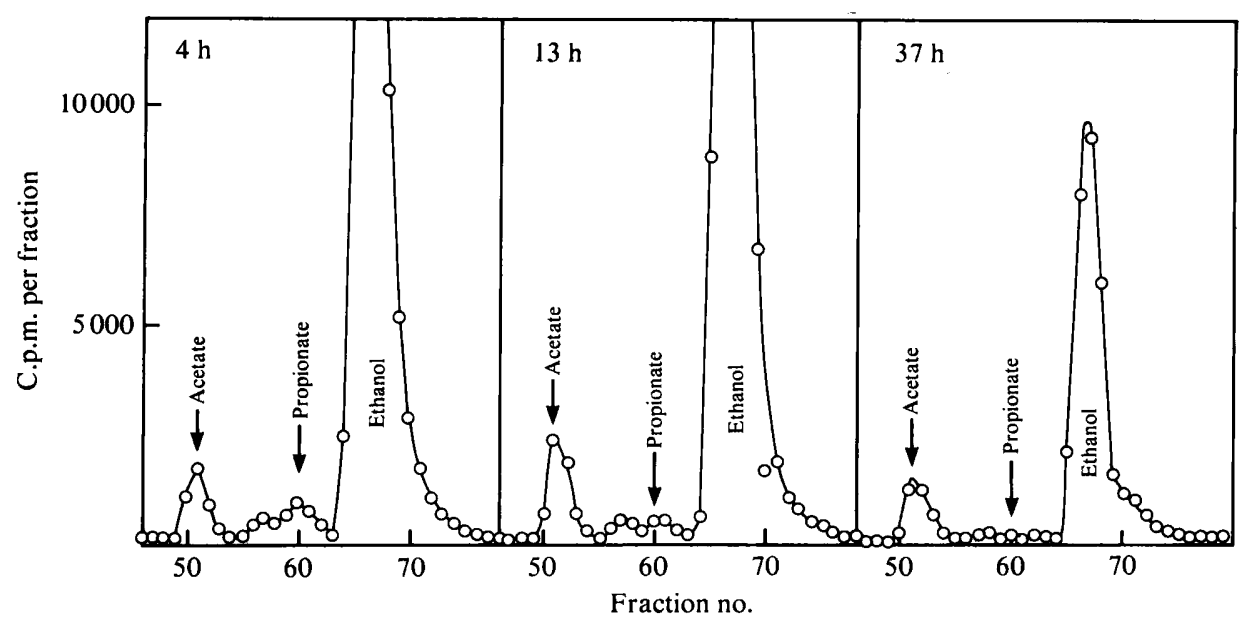

Fig. 1. Labelled degradation intermediates of $\left[1^{-14} \mathrm{C}\right]$ ethanol incubated with Knaack Lake sediment samples at the in situ temperature. The headspaces of the experimental tubes contained $\mathrm{N}_{2} / \mathrm{CO}_{2}$ mixture $(95: 5, \mathrm{v} / \mathrm{v})$.

\section{Intermediates of ethanol degradation}

Liquid degradation intermediates of labelled ethanol were separated and identified in pore water preparations by HPLC and liquid scintillation counting. Fig. 1 shows the distribution of radioactive label in separated fractions of pore water preparations of Knaack Lake sediment after 4, 13, and $37 \mathrm{~h}$ of incubation with $\mathrm{C}-1$ labelled ethanol. At the beginning of the experiment, a considerable amount of label appeared in the propionate fraction and the amount of labelled acetate was only about twice as high as that of labelled propionate. The proportion of labelled propionate to acetate decreased with time and was neglible after $37 \mathrm{~h}$ incubation. Labelled butyrate was not detected, but an unidentified peak of label appeared between acetate and propionate. The same distribution of labelled fractions was observed when C-2 labelled ethanol was used as̀ tracer.

Analysis of pore water samples of Lake Mendota sediment and sewage sludge during degradation of labelled ethanol demonstrated the intermediate appearance of labelled propionate in these samples also. However, the proportion of labelled propionate to labelled acetate was smaller (data not shown). Labelled butyrate did not appear in these samples either.

\section{Effect of hydrogen on ethanol degradation in Knaack Lake sediment}

To check whether additional electrons in the form of molecular hydrogen have an effect on the distribution of labelled intermediates of ethanol degradation, turnover experiments were run in the presence and absence of hydrogen gas (Fig. 2). Hydrogen inhibited ethanol degradation drastically, and the turnover time of C-1 labelled ethanol increased about fourfold. Only small amounts of labelled propionate were detected in the pore water during ethanol degradation but labelled butyrate could be identified after 13 and $37 \mathrm{~h}$ incubation. The unidentified peak between acetate and propionate appeared again.

\section{Enumeration of ethanol-degrading anaerobes}

Ethanol-degrading anaerobic bacteria were enumerated by the three-tube most probable number method in samples taken from all three environments. Fermentation products were analysed in the positive tubes. The results are presented in Table 3. Only a few ethanol degraders were detected in Lake Mendota sediment, and acetate and small amounts of methane were the only fermentation products. Desulfovibrio-like short curved motiles rods were observed in the last positive tubes. 


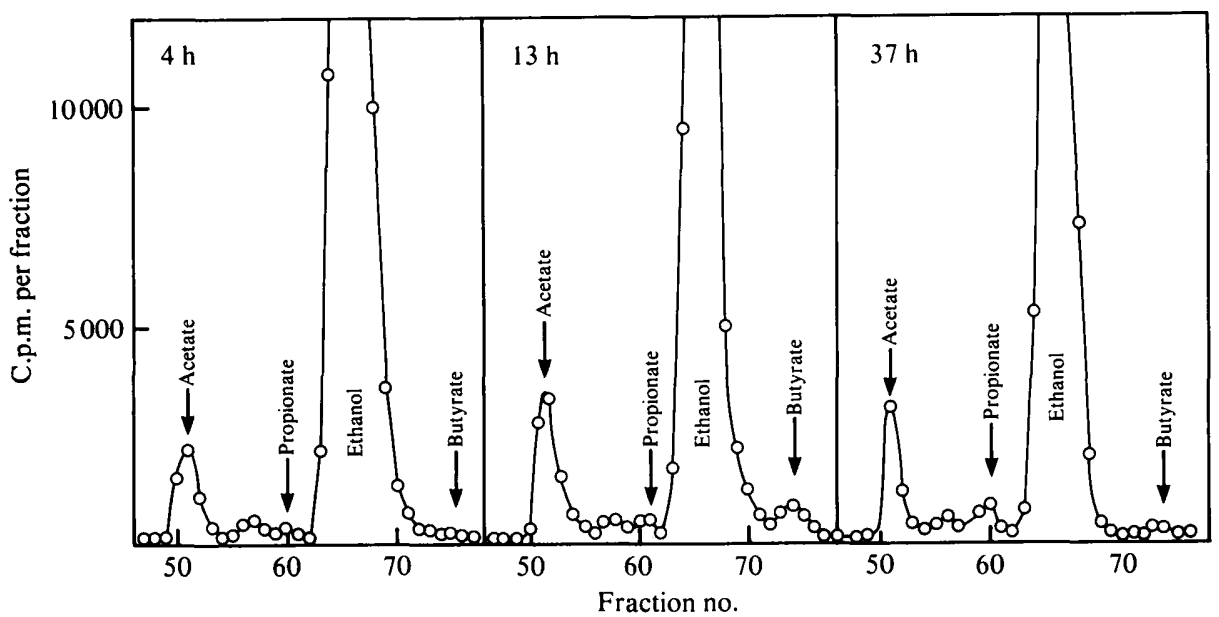

Fig. 2. Labelled degradation intermediates of $[1-1+\mathrm{C}]$ ethanol incubated with Knaack Lake sediment samples at the in situ temperature. The headspaces of the experimental tubes contained $\mathrm{H}_{2} / \mathrm{CO}_{2}$ mixture $(80: 20, v / v)$.

Table 3. Numbers and fermentation products of ethanol-degrading anaerobes in sediments of Lake Mendota and Knaack Lake and in sewage sludge

The results of a three-tube most probable number dilution series in mineral medium with $10 \mathrm{mmol}$ ethanol $\mathrm{I}^{-1}$ as the sole substrate are shown. Growth was positive at $\mathrm{OD}_{650} \geqslant 0 \cdot 1$; products were positive at $\geqslant 1.0 \mathrm{mM}$ concentration after 4 weeks incubation at $28^{\circ} \mathrm{C}$. MPN indices: Mendota, $4.6 \times 10^{2} \mathrm{ml}^{-1} ; \mathrm{Knaack}, 1.1 \times 10^{5} \mathrm{ml}^{-1}$; sewage, $4.6 \times 10^{5} \mathrm{ml}^{-1}$. Ac, acetate; Prop, propionate.

\begin{tabular}{|c|c|c|c|c|c|c|c|c|c|c|c|c|}
\hline \multirow{2}{*}{$\begin{array}{l}\text { Inoculum } \\
\quad(\mathrm{ml})\end{array}$} & \multicolumn{4}{|c|}{ Mendota } & \multicolumn{4}{|c|}{ Knaack } & \multicolumn{4}{|c|}{ Sewage } \\
\hline & Growth & Ac & Prop & $\mathrm{CH}_{4}$ & Growth & Ac & Prop & $\mathrm{CH}_{4}$ & Growth & Ac & Prop & $\mathrm{CH}_{4}$ \\
\hline $10^{-1}$ & +++ & + & \pm & \pm & +++ & + & + & + & +++ & + & \pm & + \\
\hline $10^{-2}$ & +++ & + & - & \pm & +++ & + & + & + & $+t+$ & + & + & + \\
\hline $10^{-3}$ & +-- & + & - & - & $+t+$ & + & + & + & +++ & + & + & + \\
\hline $10^{-4}$ & --- & - & - & - & +++ & + & + & - & $++t$ & + & + & + \\
\hline $10^{-5}$ & --- & - & - & - & ++- & + & - & - & +++ & + & + & + \\
\hline $10^{-6}$ & --- & - & - & - & --- & - & - & - & +-- & + & - & + \\
\hline $10^{-7}$ & --- & - & - & - & --- & - & - & - & --- & - & - & - \\
\hline
\end{tabular}

Populations of ethanol-degrading anaerobes were considerably larger in the Knaack Lake sediment than in the Lake Mendota sediment. Whereas methane, propionate and acetate were fermentation products in the lower dilution tubes, only acetate appeared in the highest positive dilution tubes. Short vibrioid rods and bigger straight rods with terminal spherical spores similar to Clostridium aceticum were observed by microscopic examination of the highest dilution tubes. Methanospirillum hungatii was the prevalent fluorescent methanogen in the lower dilution tubes.

The highest numbers of ethanol-degrading anaerobes were detected in sewage sludge. Acetate and methane were the main fermentation products; in the tubes of lower dilution, propionate was also found. The prevalent bacteria were short straight rods and Methanospirillum hungatii, whereas the lower dilution tubes also contained fat rods morphologically similar to Pelobacter propionicus or Desulfobulbus propionicus.

\section{Pure culture studies on hydrogen inhibition of ethanol degradation}

To ascertain whether hydrogen inhibited ethanol degradation in a manner analogous to that observed in the Knaack Lake sediment, the effect of hydrogen on the activity of pure cultures of 


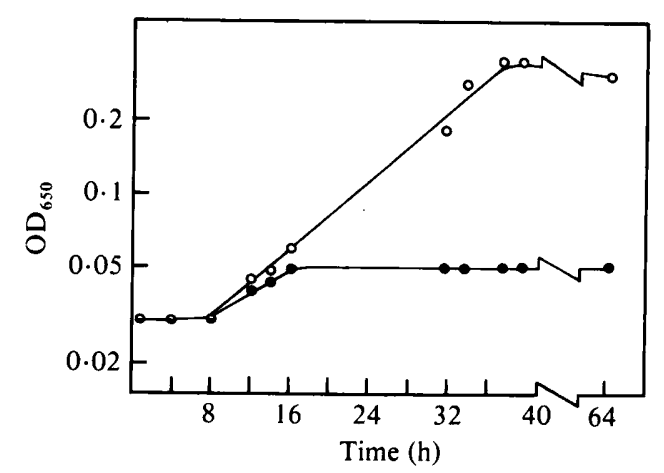

Fig. 3. Growth of Clostridium aceticum in the presence $(O)$ and absence $(O)$ of hydrogen. Mineral medium with yeast extract (Braun et al., 1981) and 20 mmol ethanol $\mathrm{l}^{-1}$ was used.

ethanol-degrading anaerobes was studied. The homoacetogenic ethanol oxidizers Clostridium aceticum and Acetobacterium carbinolicum as well as the propionate-forming Pelobacter propionicus were grown in the presence and absence of hydrogen. Growth of $C$. aceticum was dramatically inhibited by hydrogen (Fig. 3). Similar results were obtained with $P$. propionicus (data not shown) and A. carbinolicum (Eichler \& Schink, 1984). Thus, the hydrogen-dependent inhibition of ethanol degradation observed with Knaack Lake sediment can be interpreted as a direct inhibition of all types of ethanol-oxidizing bacteria involved.

\section{DISCUSSION}

The various processes by which ethanol is converted to fatty acids do not differ significantly with respect to the Gibbs free energy changes (calculations after Thauer et al., 1977):

$$
\begin{aligned}
& \mathrm{CH}_{3} \mathrm{CH}_{2} \mathrm{OH}+\mathrm{CH}_{3} \mathrm{COO}^{-} \rightarrow \mathrm{CH}_{3} \mathrm{CH}_{2} \mathrm{CH}_{2} \mathrm{COO}^{-}+\mathrm{H}_{2} \mathrm{O} \\
& \Delta G_{0}^{\prime}=-38 \cdot 8 \mathrm{~kJ} \mathrm{~mol}^{-1} \\
& 3 \mathrm{CH}_{3} \mathrm{CH}_{2} \mathrm{OH}+2 \mathrm{HCO}_{3}^{-} \rightarrow \mathrm{CH}_{3} \mathrm{COO}^{-}+2 \mathrm{CH}_{3} \mathrm{CH}_{2} \mathrm{COO}^{-}+\mathrm{H}^{+}+3 \mathrm{H}_{2} \mathrm{O} \\
& \Delta G_{0}^{\prime}=-41.5 \mathrm{~kJ}(\mathrm{~mol} \text { ethanol) })^{-1} \\
& 2 \mathrm{CH}_{3} \mathrm{CH}_{2} \mathrm{OH}+2 \mathrm{HCO}_{3}^{-} \rightarrow 3 \mathrm{CH}_{3} \mathrm{COO}^{-}+\mathrm{H}^{+}+2 \mathrm{H}_{2} \mathrm{O} \\
& \Delta G_{0}^{\prime}=-42 \cdot 8 \mathrm{~kJ}(\mathrm{~mol} \text { ethanol) })^{-1} \\
& 2 \mathrm{CH}_{3} \mathrm{CH}_{2} \mathrm{OH}+\mathrm{HCO}_{3}^{-} \rightarrow 2 \mathrm{CH}_{3} \mathrm{COO}^{-}+\mathrm{H}^{+}+\mathrm{CH}_{4}+\mathrm{H}_{2} \mathrm{O} \\
& \left.\Delta G_{0}^{\prime}=-58.3 \mathrm{~kJ} \text { (mol ethanol) }\right)^{-1} \\
& 2 \mathrm{CH}_{3} \mathrm{CH}_{2} \mathrm{OH}+\mathrm{SO}_{4}^{2-} \rightarrow 2 \mathrm{CH}_{3} \mathrm{COO}^{-}+\mathrm{H}^{+}+\mathrm{HS}^{-}+2 \mathrm{H}_{2} \mathrm{O} \\
& \Delta G_{0}^{\prime}=-66.6 \mathrm{~kJ}(\mathrm{~mol} \text { ethanol) })^{-1}
\end{aligned}
$$

The formation of butyrate from ethanol and acetate is the least exergonic reaction, whereas propionate formation and homoacetogenic acetate formation yield nearly identical amounts of energy. Oxidation of ethanol to acetate with concomitant methane formation via interspecies hydrogen transfer allows a considerably higher energy conservation, and the free energy change of this reaction is even higher if sulphate serves as the electron acceptor instead of bicarbonate. Recent studies showed that ethanol is an important fermentation intermediate in sediments of Knaack Lake and Lake Mendota (Phelps \& Zeikus, 1984; T. J. Phelps \& J. G. Zeikus, unpublished observations). The present paper confirms these findings and attributes comparable importance to ethanol transformation in sewage sludge fermentations. Comparison of the distribution of radioactive carbon in the methane and carbon dioxide fractions after fermentation of differently labelled acetate and ethanol tracers demonstrated that there was far more exchange between the $\mathrm{C}-1$ and $\mathrm{C}-2$ atoms of ethanol than between the respective atoms of labelled acetate. This indicates that ethanol was not exclusively metabolized via acetate. 
(a)

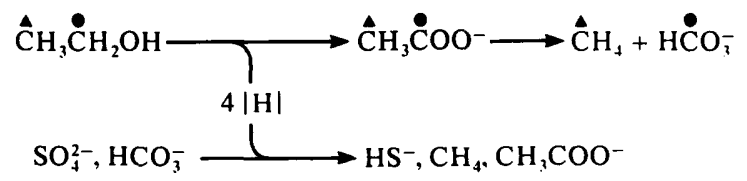

(b)

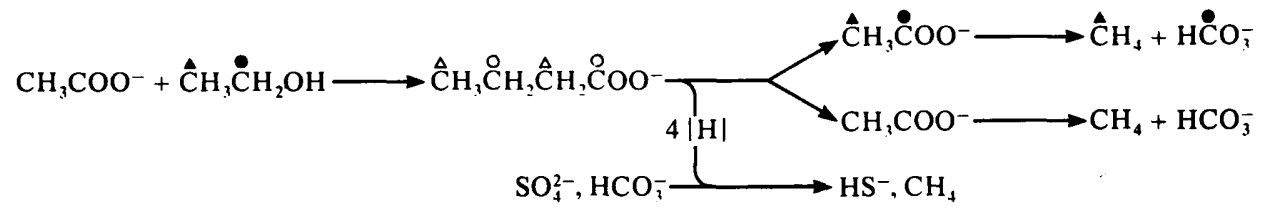

(c)

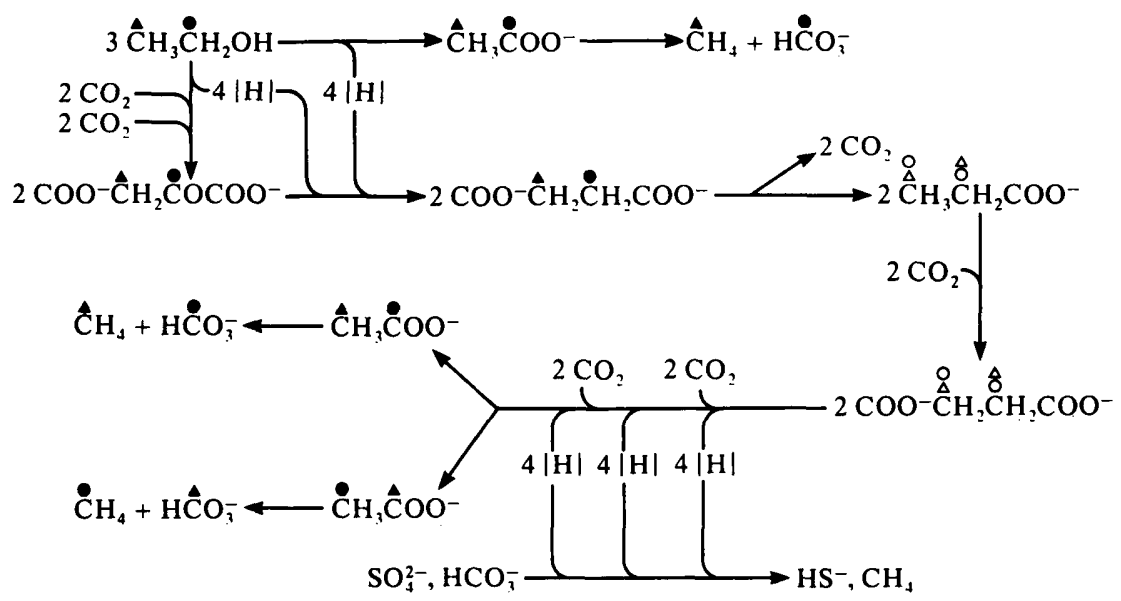

Fig. 4. Metabolic pathways of anaerobic ethanol degradation via (a) acetate, $(b)$ butyrate or $(c)$ propionate. Labelled carbon atoms are indicated by symbols: circles, C-1; triangles, C-2 (original positions of the labels in ethanol); open symbols are used when there are two possible positions for the label.

Fig. 4 compares the various mechanisms of anaerobic ethanol degradation with respect to the fate of the carbon atoms. It appears that the pathways which involve only acetate and butyrate as intermediates (Fig. $4 a, b$ ) always end up with the same pattern of label distribution. Ethanol is converted to acetate without exchanging the position of the carbon atoms. Since cleavage of acetate by the methanogenic bacteria converts the bulk of the $\mathrm{C}-1$ - atom to carbon dioxide and the C-2 atom to methane (Buswell \& Sollo, 1948; Wolfe, 1980; Krzycki et al., 1982), the C-1 and $\mathrm{C}-2$ carbon atoms of ethanol should appear as carbon dioxide and methane in the same ratio as the respective acetate atoms.

Conversion of ethanol to propionate by Desulfobulbus propionicus (Stams et al., 1984) and Pelobacter propionicus (B. Schink, unpublished data) proceeds via a randomizing pathway including succinate, and methanogenic propionate oxidation uses the same pathway (Koch $e t$ al., 1983; Schink, 1985). Methanogenic ethanol degradation via propionate, therefore, would end up with two-thirds of the $\mathrm{C}-1$ atoms as carbon dioxide and one-third as methane, and conversely one-third of the C-2 atoms would end up as carbon dioxide and two-thirds as methane (Fig. $4 c$ ). Enhanced exchange of the carbon atoms of ethanol compared to those of acetate, therefore, indicates that propionate is involved as an intermediate in ethanol degradation. In the present study, the distribution of the $\mathrm{C}-1$ and $\mathrm{C}-2$ atoms of acetate in the carbon dioxide and methane fractions, respectively, was found to follow more or less the expected ratios. A 
comparably high proportion of the C-2 atom of acetate was oxidized to carbon dioxide in the Lake Mendota and Knaack Lake sediments. These findings can be attributed to sulphate reduction in Lake Mendota (Ingvorsen et al., 1981) and unknown exchange reactions in Knaack Lake (Phelps \& Zeikus, 1984). The labelled C-1 and C-2 atoms of ethanol, however, appeared to a greater extent than the respective acetate atoms as methane and carbon dioxide, respectively. The ratio of exchanged label was $10 \%$ and more in all three environments. Even if only part of this exchange is due to the randomizing reactions described above, these results indicate that a considerable volume $(\leqslant 30 \%)$ of ethanol degradation proceeds through propionate. Thus, ethanol degradation would account for the major part of total propionate metabolism in the environments studied (Schink, 1985). Conversion of ethanol to propionate was also demonstrated by tracer studies coupled with HPLC and liquid scintillation counting techniques.

Addition of hydrogen to Knaack Lake sediment samples inhibited ethanol degradation drastically, a phenomenon observed earlier with sewage sludge samples (Kaspar \& Wuhrmann, 1978). If this effect were only due to product inhibition of syntrophic ethanol oxidizers like the 'S-organism' (Bryant et al., 1967; Reddy et al., 1972) one would expect under these conditions a far higher proportion of ethanol to be fermented via propionate. However, the pool of labelled propionate in the pore water was not increased by hydrogen, and the balance of labelled methane and carbon dioxide formed was not significantly changed. Pure culture studies demonstrated that all metabolic types of ethanol-degrading anaerobes, including the homoacetogenic and the propionate-forming bacteria, were inhibited by hydrogen, and thus explained why there was no significant alteration in the fermentation mechanisms. An inhibitory effect of hydrogen on fructose and lactate degradation was found earlier with Acetobacterium woodii and Clostridium aceticum (Braun \& Gottschalk, 1981). An interesting side effect of hydrogen addition to Knaack Lake sediment was the formation of labelled butyrate from ethanol. Butyrate did not appear to be involved in ethanol degradation under in situ conditions in any of the environments studied. The conversion of ethanol to butyrate in the presence of excess hydrogen may indicate that bacteria metabolically similar to Clostridium kluyveri (Barker, 1937; Bornstein \& Barker, 1948) are present in this sediment, but are not involved in ethanol degradation under in situ conditions. Formation of labelled butyrate from labelled acetate and excess hydrogen by syntrophically butyrate-oxidizing bacteria like Syntrophomonas wolfei (McInerney et al., 1979) could be another explanation for this result.

Ethanol-degrading anaerobes were enumerated in all three environments by the MPN method in order to estimate the population sizes and to characterize the predominant organisms. It has to be emphasized that results of MPN enumerations only refer to a small fraction of the total microbial population present in an environment, and that the ecological value of such enumerations is limited by the cultivation conditions. Only a few ethanol-oxidizing bacteria were found in the Lake Mendota sediment, and the prevailing bacteria were morphologically similar to Desulfovibrio $\mathrm{sp}$. This is not surprising since sulphate reduction is an important process in anaerobic mineralization in this environment in early summer (Ingvorsen et al., 1981).

In Knaack Lake sediment, homoacetogenic ethanol oxidizers morphologically similar to Clostridium aceticum were found to be prevalent, although this species has been described as slightly alkaliphilic ( $\mathrm{pH}>7 \cdot 0$ ) (Braun et al., 1981). In this sediment, methane is formed nearly exclusively from acetate $(94 \%)$ and only to a small extent from hydrogen and carbon dioxide (Phelps \& Zeikus, 1984). The preponderance of a homoacetogenic bacterial population for anaerobic ethanol degradation in this lake fits into the same picture. In the lower dilution tubes, however, propionate-forming anaerobes successfully competed for ethanol with the homoacetogens, indicating that they were able to outcompete the homoacetogens if ethanol was provided at high concentrations.

In sewage sludge, a syntrophic methanogenic system similar to 'Methanobacillus omelianskii' was found to be numerically predominant in ethanol degradation. However, here also propionate was formed in the lower dilution tubes indicating that the propionate-forming ethanol oxidizers although present in small numbers were successful competitors even against the thermodynamically favoured methanogenic system if ethanol was provided at high concentrations. 
The authors thank Dr J. C. Ensign for fruitful discussions and for providing ultra-pure water for HPLC. Thanks are also due to Professor Dr N. Pfennig and the Fakultät für Biologie, Universität Konstanz, for allowing ten weeks' research leave in Madison, Wisconsin, USA. Financial support by the Deutsche Forschungsgemeinschaft and the Department of Energy, grant no. DE-AC02-80ER10705, is gratefully acknowledged.

\section{REFERENCES}

American Public Health Association (1969). Standard Methods for the Examination of Wastes and Wastewater Including Bottom Sediments and Sludge, pp. 604-609. New York: American Public Health Association.

BARKER, H. A. (1936). On the biochemistry of the methane fermentation. Archives of Microbiology 7, 404-419.

BARKER, H. A. (1937). The production of caproic and butyric acids by the methane fermentation of ethyl alcohol. Archives of Microbiology 8, 416-421.

BornsteIn, B. T. \& BARKer, H. A. (1948). The energy metabolism of Clostridium kluvteri and the synthesis of fatty acids. Journal of Biological Chemistry 172 , 659-669.

Braun, K. \& Gottschalk, G. (1981). Effect of molecular hydrogen and carbon dioxide on chemoorganotrophic growth of Acetobacterium woodii and Clostridium aceticum. Archices of Microbiology 128 , 294-298.

Braun, M., Mayer, F. \& Gottschalk, G. (1981). Clostridium aceticum (Wieringa), a microorganism producing acetic acid from molecular hydrogen and carbon dioxide. Archices of Microbiology 128, 288293

Bryant, M. P., Wolin, E. A., Wolin, M. J. \& Wolfe, R. S. (1967). Methanobacillus omelianskii, a symbiotic association of two species of bacteria. Archives of Microbiology 59, 20-31

Bryant, M. P., Campbell, L. L., Reddy, C. A. \& Crabill, M. R. (1977). Growth of Desulfotibrio in lactate or ethanol media low in sulfate in association with $\mathrm{H}_{2}$-utilizing methanogenic bacteria. Applied and Encironmental Microbiology 33, 1162-1169.

Buswell, A. M. \& Sollo, F. W. (1948). The mechanism of methane fermentation. Journal of the American Chenical Society 70, 1778-1780.

EICHLER, B. \& SCHINK, B. (1984). Oxidation of primary aliphatic alcohols by Acetohacterium carbinolicum sp. nov., a homoacetogenic anaerobe. Archires of Microbiolog! (in the Press).

Iannotti, E. T., Kafkewitz, D., Wolin, M. J. \& BRyant, M. P. (1973). Glucose fermentation products of Ruminococcus albus grown in continuous culture with Vibrio succinogenes: changes caused by interspecies transfer of $\mathrm{H}_{2}$. Journal of Bacteriology. 114. $1231-1240$

Ingvorsen, K., Zeikus, J. G. \& Brock, T. D. (1981). Dynamics of bacterial sulfate reduction in a eutrophic lake. Applied and Entironmental Microbiolog. 42, 1029-1036.

Kaspar, H. F. \& Wuhrmann, K. (1978). Product inhibition in sludge digestion. Microbial Ecology 4, 241-248.

Koch, M., Dolfing, J., Wuhrmann, K. \& Zehnder, A. J. B. (1983). Pathways of propionate degradation by enriched methanogenic cultures. Applied and Entironmental Microbiology 45, 1411-1414.
KrzyCKI, J. A., Wolkin, R. H. \& ZeIKUS, J. G. (1982). Comparison of unitrophic and mixotrophic substrate metabolism by an acetate-adapted strain of Methanosarcina barkeri. Journal of Bacteriology 149, 247-254.

LaAnbroek, H. J., Abee, T. \& Voogd, J. L. (1982). Alcohol conversions by Delsulfobulbus propionicus Lindhorst in the presence and absence of sulfate and hydrogen. Archices of Microbiology 133, 178-184.

LOVLEY, D. R. \& KLUG, M. J. (1982). Intermediary metabolism of organic matter in the sediments of a eutrophic lake. Applied and Encironmental Microbiology 43, 552-560.

MCInerney, M. J., Bryant, M. P. \& Pfennig, N. (1979). Anaerobic bacterium that degrades fatty acids in syntrophic association with methanogens. Archives of Microbiology 122, 129-135.

Phelps, T. J. \& Zeikus, J. G. (1984). Influence of pH on terminal carbon metabolism in anoxic sediments from a mildly acidic lake. Applied and Encironmental Microbiology' (in the Press).

Postgate, J. R. (1979). The Sulphate-reducing Bacteria. Cambridge: Cambridge University Press.

ReDDY, C. A., BRYANT, M. P. \& Wolin, M. J. (1972). Characteristics of S organism isolated from Methanobacillus omelianskii. Journal of Bacteriology 109, 539545.

Samain, E., Albaniac, G., Dubourgier, H. C. \& TouzeL, J. P. (1982). Characterization of a new propionic acid bacterium that ferments ethanol and displays a growth factor dependent association with a Gram-negative homoacetogen. FEMS Microhiology Letters 15, 69-74.

Schink, B. (1984). Fermentation of 2,3-butanediol by Pelohacter carbinolicus sp. nov. and evidence for propionate formation from $\mathrm{C}_{2}$ compounds. Archites of Microbiology 137, 33-41.

SCHINK, B. (1985). Mechanism and kinetics of succinate and propionate degradation in anoxic freshwater sediments and sewage sludge. Journal of General Microbiology 131, 643-650.

Schink, B. \& Zeikus, J. G. (1982). Microbial ecology of pectin decomposition in anoxic lake sediments. Journal of General Microbiology 128, 393-404.

Stams, A. J. M., Kremer, D. R., Nicolay, K., Wenk, G. H. \& Hansen, T. A. (1984). Pathway of propionate formation in Desulfobulbus propionicus. Archites of Microbiology 139, 167-173.

Tewes, F. J. \& Thauer, R. K. (1980). Regulation of ATP-synthesis in glucose fermenting bacteria involved in interspecies hydrogen transfer. In Anaerobes and Anaerobic Infections. Edited by G. Gottschalk, N. Pfennig \& H. Werner. Stuttgart \& New York: G. Fischer Verlag.

Thauer, R. K., Jungermann, K. \& Decker, K. (1977). Energy conservation in chemotrophic anaerobic bacteria. Bacteriological Reviews 41, $100-180$. 
WeIMER, P. J. \& ZeIKUS, J. G. (1977). Fermentation of cellulose and cellobiose by Clostridium thermocellum in the absence and presence of Methanobacterium thermoautotrophicum. Applied and Environmental Microbiology 33, 289-297.

Widdel, F. \& PfenNig, N. (1981). Studies on dissimilatory sulfate-reducing bacteria that decompose fatty acids. I. Isolation of new sulfate-reducing bacteria enriched with acetate from saline environments. Description of Desulfobacter postgatei gen. nov., sp. nov. Archives of Microbiology 129, 395400.

WolfE, R. S. (1980). Respiration in methanogenic bacteria. In Diversity of Bacterial Respiratory Systems, vol. 1, pp. 161-186. Edited by C. J. Knowles. Boca Raton, Florida: CRC Press. 